\title{
Post-structuralism and Eastern Epistemology: the Concordance in Discordance
}

\begin{abstract}
Dhanuka Bandara
University of Peradeniya, Sri Lanka

Abstract

The objective of this paper is to analyse the fascinating ties between German transcendental philosophy of the $19^{\text {th }}$ century and the Upanishadic and Buddhist thought, and the myriad ways in which these ties bear upon later European philosophy. My paper argues that Arthur Schopenhauer's World as Will and Idea-which heavily draws upon the Upanishads and Buddhism-is the point of provenance of what I describe as a "Genealogy of Thought" in western philosophy. Therefore in this paper I trace the influence of Schopenhauer-and in turn that of the Upanishads and Buddhismin the work of Friedrich Nietzsche, Sigmund Freud and Jacques Derrida. These three thinkers are closely associated with the poststructuralist project. It is my contention that the antecedents of post structuralism can be discerned in the Upanishads and Buddhism. Many fundamental tenets of poststructuralist thought such as the deconstruction of binary opposites, the Heideggerian critique of presence and self, and non-linearity resonate certain key positions held by classical Indian philosophers. I further go on to argue that the genealogy of thought that I am tracing is at odds with what could be broadly described as "traditional western metaphysics"; that the influence of the Upanishads and Buddhism afforded the thinkers that I am discussing a critical reflection on western thought. For this reason postcolonial theorists such as Gayathri Spivak and Homi K. Bhabha freely avail themselves of poststructuralist theory. This is because poststructuralist theory, as I argue in this paper, has its roots in the colonial encounter itself.
\end{abstract}

Keywords: metaphysics, post structuralism, the Upanishads

There are many affinities between post-structuralism and post colonialism. Postcolonial theory freely draws upon the rich resources of post-structuralism in order to achieve its own epistemological and political ends. Often postcolonial theorists such as Gayatri Spivak and Homi K. Bhabha seem to borrow their primary theoretical wherewithal from "western epistemology"-by and large the radical philosophical theories developed by 
philosophers such as Jacques Derrida, Michel Foucault, Sigmund Freud and the latter's twentieth century successor Jacques Lacanin order to formulate a critique of western colonialism. There are many points of intersection, possible lines of influence between post-structuralism and pre-colonial Indian philosophy. However, a systematic and comprehensive analysis of the interconnections between $19^{\text {th }}$ century German thought, classical Indian philosophy and $20^{\text {th }}$ century French post-structuralism is yet to be undertaken. Such a strenuous undertaking-which would be, nevertheless, immensely rewarding - requires a sound knowledge of at least four languages: German, Sanskrit, French and English and an extensive understanding of philosophy - Western and Eastern. Therefore, my own paper on the subject will be at best, I hope, a useful point of departure.

In this paper, I do not attempt to find "antecedents" or origins of post-structuralism in Eastern epistemology. Such quests for origins are inane and are rendered suspect after Michel Foucault's TheArchaeology of Knowledge; nor do I attempt to establish a genealogy of influence, a tradition of ideas in Western epistemology that is informed by the Upanishads and Buddhism. According to Foucault, tradition is:

“(...) Intended to give a special temporal status to a group of phenomena that are both successive and identical (or at least similar); it makes it possible to rethink the dispersion of history in the form of the same; it allows a reduction of the different proper to every beginning, in order to pursue without discontinuity the endless search for the origin; tradition enables us to isolate the new against a background of permanence, and to transfer its merit to originality, to genius." (Foucault 24)

Therefore to think of ideas in terms of tradition is to impose upon dispersion a totalizing interpretation and to relegate new ideas to origins. Therefore my study is an attempt to discern the possible moments of concordance between Eastern and Western philosophy. I will not attempt to establish direct lines of causal connection between two seemingly distinct systems of knowledge; nor am I claiming that post-structuralism would not have happened in the absence of the colonial encounter. Nevertheless that there are connections between Eastern and Western thought, that Eastern philosophy influenced $19^{\text {th }}$ century German thought cannot be denied. 
It was arguably Arthur Schopenhauer who brought the Upanishads to the attention of European philosophy. In his magnum opus, The World as Will and Idea ${ }^{1}$ (WWI), Schopenhauer has no reservations about the significance of the Upanishads. In fact he describes the Upanishads as the highest achievement of human intellect. WWI, published in 1819,is a groundbreaking text in more than one respect. Schopenhauer was one of the first European philosophers to radically question the fundamental values of European enlightenment. In Schopenhauer's thought, reason and rational thinking come under withering critique. The $18^{\text {th }}$ century-the century of enlightenment-was described as the "age of reason" on account of its emphasis on rational thinking. Order, structure, linearity and discipline are seen as correlatives of reason. Schopenhauer was not in agreement.

Immanuel Kant's conceptualization of "noumena" or that which exists outside time, space and causality, which for that reason Kant describes as the "thing-in-itself," profoundly influenced Schopenhauer. The Kantian "thing-in-itself" is not within the realm of reason because it exists outside space, time and causality. Therefore there is no way of knowing what it is, except that it cannot be known. Reason is only concerned with things that can be known and rationalized. In this way Schopenhauer disclosed the inadequacy of reason. His thinking attempted to dislodge the position of superiority that the European enlightenment assigned to reason.

Although in Schopenhauer's thought one can clearly discern the influence of Plato and Kant, it is the crucial influence of the Upanishads and Buddhism that renders him a virulent critic of what could be described as "traditional western epistemology." The famous first line of WWI: "The world is my idea" (Schopenhauer 3) suggests that there is no objective truth outside perception; that what we perceive as reality is what we perceive as such and that reality has no existence in itself. This is one of the fundamental tenets of Schopenhauer's book. In the second page itself he acknowledges his debt to the Vedas: "On the other hand how early this truth was recognized by the wise men of India, in that it features as Vyasa, is pointed out by Sir William Jones in the last of his essays (...)" (Schopenhauer 4). Later, in the all-important Book

\footnotetext{
${ }^{1}$ Hereafter referred to as $W W I$.
} 
IV, titled "The Affirmation and the Denial of the Will to Life" he would say the following about the Vedas: "the fruit of the highest human knowledge and wisdom, the kernel of which has at last become accessible to us in the Upanishads as the greatest gift of this century" (Schopenhauer 220). Schopenhauer's reverence for the Vedas is expressed well enough and without qualification. What is even more interesting is how this influences his thinking.

Advaita Vedanta-an important and influential branch of Hinduism - lays stress on the idea of non-duality. There is no distinction between Brahman and the world; rather Brahman is the transcendental unity that manifests itself in every being and thing. It is the veil of maya that prevents us from seeing this "truth" and makes us perceive the world in all its plurality. Thus, individuality is a mere illusion, which results from the false distinction we make between Self and Other. The Upanishads posits that once the illusion (maya) of duality is replaced by "Spirit" one cannot know the Other; the knowledge of the Other is thus precluded. The following quote from Brihad-Aranayaka Upanishads amply crystallizes this idea:

"For where there seems to be a duality, there one sees another, one hears another, one feels another's perfume. One thinks of another, one knows another. But when all has become Spirit, one's own Self, how and whom could one see? How and whom could one hear? How and whom could one feel the perfume? How and whom could one speak? How and whom could one know? How can one know him who knows all? How can the Knower be known?" (The Upanishads 132)

Thus the essence of the Upanishads is diametrically opposed to traditional western metaphysics. As Derrida explains in Positions, western epistemology is predicated upon binary divisions. Derrida, elaborating on his idea of differance-which is one of the most important terms in Derridian thinking-claims that: "(...) the movement of differance, as that which differentiates, is the common root of all the oppositional concepts that mark our language, such as, to take only a few examples, sensible/intelligible, intuition/signification, nature/culture, etc." (Derrida 7) What is deconstructed in the Upanishads is perhaps the most fundamental of all such binary divisions: the Self/Other binary. This is the binary on which "Discourses of Othering" such as colonialism, orientalism, nationalism, racism etc, rest. The Upanishads bring the Self/Other 
binary to severe crisis by positing that individuality or the Self does not really exist. Within the contours of an epistemological system that denies the being of Self, discourses of Othering simply cannot $b e$, or be conceived. It is this insight that Schopenhauer brings to western philosophy; an insight that deconstructs the very metaphysical foundation on which western philosophy stands.

In Schopenhauer, it is what he describes as "Will" that objectifies itself in everything that we perceive. We perceive the world in all its plurality because of illusion or maya (Schopenhauer uses this word repeatedly in $W W I$ ). Thus, what we perceive as Self and Other are nothing more than manifestations of the same will. The distinction between Self/Other, subject/object is only possible as long as.one subscribes to what is described in philosophy as "principium individuationis"." For Schopenhauer "principium individuationis" is only an illusion, therefore plurality is also an illusion. The Will remains indivisible: it remains as one. Schopenhauer further explains: "(...) it is one not in the sense in which an individual or a concept is one, but as something to which the potential for plurality, the principium individuationis, is an alien condition" (Schopenhauer 59). It is in this way that Schopenhauer's conceptualization of "Oneness" becomes a rejection of the Self/Other division.

Human life is one of endless suffering and dissatisfaction because the Will that manifests itself through everyone is insatiable. Then, for Schopenhauer, only the denial of this will can bring true happiness. Schopenhauer claims that once the human beings suppress the Will-the desiring and endless longing (especially sexual) - the world will be reduced to nothingness. Of course, the similarity between Schopenhauer's position and Buddhism is striking. Schopenhauer himself acknowledges his debt to Buddhism in WWI. Schopenhauer's Buddhist turn rendered him a critic of western civilization and I will also argue a critic of the western colonial project. A detailed analysis of Buddhism and Schopenhauer could be found in a book titled "Schopenhauer and Buddhism" by Bhikku Nanajivako. To quote Bhikku Nanajivako at some length:

"Schopenhauer's thesis is based on a critical revision of the theory of categories in Kant's philosophy. Kant's twelve categories (or "pure concepts of understanding") are reduced to only one-causality. In his extensive Criticism of the Kantian Philosophy, at the end of WWI, Schopenhauer

${ }^{2}$ Principium Individuationis refers to the grounds on which one conceives of oneself as a being distinct from other beings. 
pointed out that Kant's conception of the whole problem still remained too strongly influenced by the typically European, Aristotelian and Scholastic tradition and that he was unable renounce the idea of a "first cause" in the "chain of causes and effects", but still felt tempted to consider this idea in connection with the idea of God, of the immortality of the soul and of the freedom of the will as necessarily innate in the very nature of human Reason. To dispel this error, Schopenhauer, in his main work (WWI), used against Kant the historical argument of Indian philosophy essential especially to Buddhism. " (Bhikku Nanajivako 3)

The above quoted passage amply illustrates that it was Buddhism that made it possible for Schopenhauer to formulate a critique of Kantian metaphysics and in so doing distance his own philosophy from traditional western metaphysics of the Aristotelian tradition. It should be noted here that Schopenhauer shares-at least to some degree - with the poststructuralists, his criticism of traditional western philosophy.

The following lines illustrate Schopenhauer's criticism of colonialism. Commenting on western missionaries in India he writes:

"But what will happen to us is the same as what happens to the man who fires a bullet at a rock-face. In India our religion will never take root. The primeval wisdom of the human race will not be displaced by what happens in Galilee. On the contrary, Indian philosophy flows back to Europe, and will make a fundamental change in our scholarship and in our thinking." (Schopenhauer 222)

The significance of this passage, I suppose, is obvious to any contemporary reader. It should also be mentioned that Schopenhauer wrote so in 1819 when hardly any leading European intellectual questioned colonialism. Even Karl Marx who was one of the brightest minds of the 19th century had his blinders on when it came to colonialism. In fact his essay "The British Rule in India" amounts to a disgraceful justification of colonialism. In this essay he argues that capitalism made possible the only revolution in India. Thus it is colonialism that can liberate India from what he describes elsewhere as "Oriental Despotism." A critique of Marx's reading of the orient and its economic system(s) can be found in Edward Said's Orientalism. 
However, it should be noted that Schopenhauer was not immune to the orientalist idée recu of $19^{\text {th }}$ century Europe. In fact he has no scruples about calling the Indians-in spite of his unreserved admiration of Indian philosophy-a "degenerate race". However, what is important is that despite this, Schopenhauer predicts the failure, long before it materialized, of British colonialism in India.

Schopenhauer's thinking significantly bore upon that of Nietzsche. The latter taught the world to philosophize with a hammer. Although in his later works Nietzsche distanced himself from Schopenhauer, in Twilight of the Idols Nietzsche claims that Schopenhauer is the "last German philosopher worthy of consideration." If at all Nietzsche was a student of Schopenhauer, he was a bad student. That Nietzschean Will to Power is a modification of Schopenhauer's Will to Life is obvious enough. However, it seems that unlike Schopenhauer who insists that the Will to Life should be curbed, Nietzschean ubermanch or superman asserts his Will to Power at any cost. In this way it seems that Nietzsche divorces himself from the pacifist politics of his predecessor. In the following century, Adolf Hitler would claim that Nietzsche shaped his fascist worldview. Many have attempted to absolve Nietzsche of the taint of fascism. Yet, I suppose, unless one is over charitable, it is not too difficult to discern the fascist bent of Nietzsche's works such as Beyond Good and Evil and Human all too Human.

Nevertheless, Nietzsche is important to this study because he is widely considered to be a pivotal influence on Jacques Derrida as well as poststructuralist theory on the whole. Derrida acknowledges his debt to Nietzsche in his works such as Positions and "Structure, Sign and Play" in Writing and Difference. In the latter, Derrida talks in terms of a "rupture" in Western epistemology that was occasioned by thinkers such as Nietzsche and Sigmund Freud. This "rupture," according to Derrida, disrupted the replacement of "centre for centre" (Derrida 916) in western thought and paved the way for a radical "decentering" of structure. It is interesting to note that both Nietzsche and Freud were influenced by Schopenhauer.

Schopenhauer's influence on the thought of Nietzsche becomes abundantly clear to any reader of the latter's treatise on aesthetics, The Birth of Tragedy. In this important work, Nietzsche develops his aesthetic theory which posits that "great art" strikes a balance 
between what he describes as "Apollonian" and "Dionysian" opposites. These impulses, according to Nietzsche, are the two fundamental principles that inform and shape art. The principal trait of the Apollonian impulse is its stress on self and individuality. In the same vein as Schopenhauer, Nietzsche views individuality as an illusion. In fact he uses the word maya to describe the Apollonian conception of individuality. The Dionysian impulse, on the other hand, destroys one's sense of individuality. Nietzsche argues that Dionysian art forms such as the Greek Attic tragedy, dancing and music necessarily attempt to dispense with individuality. That art is able to lift the individual out of his sense of self and enables him to liberate himself from willing is Schopenhauer's stance. However, the idea that art is outside reason and logic comes from Immanuel Kant's A Critique of Judgment. Both Schopenhauer and Nietzsche subscribe to this view. Schopenhauer argued that it was possible to deny the will by immersing oneself in the contemplation of art especially music (Schopenhauer 108). Nietzsche takes his cue from Schopenhauer and argues that Dionysian art destroys individuality and that a balance between Apollonian and Dionysian impulses can be found in the finest works of art. What Nietzsche attempts here, in much the same way as Schopenhauer, is to critique and demolish the Self/Other binary. The Self/Other binary in my opinion is the most fundamental of all binary opposites. It is necessary to observe that Apollonian and Dionysian impulses embody many major Manichean divisions in western thinking such as reason/madness, order/disorder, structure/post-structure and so on. Therefore, it could be argued that according to Nietzsche, great art is necessarily a deconstructive gesture; a compromise and a harmony between opposites.

As I have mentioned above, Jacques Derrida in Positions and elsewhere argues that western epistemology is predicated upon binary opposites. Derrida's deconstruction is seen as an attempt to violently discard binary opposites. This deconstructive thrust can be seen in the works of Schopenhauer and Nietzsche. The fact that Schopenhauer's critique of the Self/Other binary and in turn that of Nietzsche is shaped by the Vedic understanding of individuality as the result of maya, establishes an undeniable link between Indian philosophy and poststructuralist theory. I am by no means implying here a causal link, however: that without the former the latter cannot happen, that without the Upanishads, post-structuralism could not have happened. I am only highlighting an idea flow, a line of influence. 
It is also worth observing that as The Birth of Tragedy evidences, Nietzsche was a critic of Socratic logic. Nietzsche describes Socrates as a necessarily anti-Dionysian philosopher. Socrates is described by Nietzsche as a "despotic logician" (Nietzsche 262) who repudiated all Dionysian art. Of course, Socrates' withering attack on art-especially poetry-in Plato's Phaedrus and Republic is well known. Jacques Derrida's essay titled, "Plato's Pharmacy" in Dissemination is a deeply perceptive and deconstructive reading of Phaedrus and a belligerent engagement with western metaphysics. In this essay, by disclosing the contradictions in Plato's text, Derrida formulates a fascinating and strident critique of logocentrism in western metaphysics. In Derrida's essay, one finds an extension of Nietzsche's earlier critique of Socrates. Derrida's rejection of the "Father of Logos" carries resonances of the Nietzschean idea of becoming one's own father.

The idea of eternal recurrence is central to the thinking of Nietzsche. Nietzsche elaborates on eternal recurrence in his works such as Thus Spake Zarathustra and more notably in The Gay Science. In the latter he describes eternal recurrence as the "heaviest burden." He further writes that: "The eternal hour glass of existence will be turned again and again - and you with it you dust of dust!" (Nietzsche 341). Eternal recurrence is a departure from western teleological thinking. The idea that life unravels itself in cycles is a central contention in eastern epistemology, whereas in traditional western thinking there is a progression towards what is described as telos. The best example of western teleology is the Bible, which starts with God creating the world and ends with the Apocalypse. It is in this way that Nietzsche's eternal recurrence amounts to a critique of western metaphysics. Not only Nietzsche, Karl Marx too maintained that history is cyclic; that it repeats itself. Let me paraphrase here the famous opening of Marx's $18^{\text {th }}$ Brumaire of Louis Bonaparte: "History repeats, first as tragedy second as farce" (Marx 15).

In Thus Spake Zarathustra, Nietzsche, having infamously and stridently declared, "God is dead" (Nietzsche 5) further asserts that he will only believe in a "God who knows how to dance." In fact, there is a great deal of dancing in Thus Spake Zarathustra. This is consonant with Nietzsche's understanding of dancing as a 
Dionysian form of art that annihilates the dancer's sense of self ${ }^{3}$. It is also important to note that the apocalyptic dance of the dancing god Nataraj-one of Shiva's avatars-brings the world, as we-know it to its end. Perhaps it is not too farfetched to argue that Hinduism for Nietzsche, like it was for his predecessor Schopenhauer, was a substitute religion.

Alongside Nietzsche and Heidegger, Derrida mentions Sigmund Freud as one of the thinkers that caused the "rupture" in western philosophy that he discusses in "Structure, Sign and Play". For Freud the whole of human accomplishments is merely the result of sublimated desire. The prominence that Freudian psychoanalysis assigns to human sexuality appears to be an echo of Schopenhauer's understanding of human sexuality as the most relentless form of Will to Life. In the last chapter of WWI, titled "The Metaphysics of Sexual Love," Schopenhauer argues that the sexual impulse is the most undeniable objectification of Will to Life; that the sexual impulse is the desire to propagate one's individuality beyond oneself by procreating. It is not difficult to see how the denial of the sexual impulse can automatically lead to nothingness. Schopenhauer's position is certainly in agreement with the celibate asceticism endorsed by Buddhism and Hinduism.

Freud acknowledges his debt to Schopenhauer in "A Difficulty in the Path of Psychoanalysis." He writes: "...above all (our forerunners) is the great thinker Schopenhauer, whose unconscious 'Will' is equivalent to the mental instinct of psychoanalysis. It was this same thinker, moreover, who in unforgettable words admonished mankind of the importance, still so greatly underestimated by it, of its sexual craving." Jacques Derrida was influenced by both Nietzsche and Freud and as I have mentioned above, Derrida considered the work of Freud and Nietzsche (along with that of Martin Heidegger) to be a "rupture" in western epistemology. Both Freud and Nietzsche broke away from the existing western philosophical tradition and formulated a critique of it. It is for this reason that their works constitute a rupture. The fact that both these important thinkers were influenced by Schopenhauer cannot be coincidental. In his essay titled, "Schopenhauer-A Link Between

\footnotetext{
${ }^{3}$ Here one is yet again reminded of W.B. Yeats' "How can one know the dancer from the dance?" from "Among School Children." There is also a good deal of dancing in D.H. Lawrence's novels such as Lady Chatterley's Lover and The Plumed Serpent. In my opinion the influence of Eastern thought on British modernist writing is, by any standard, considerable.
} 
the Buddha and Freud," M.W. Padmasiri de Silva concludes that "the close agreement between Buddhism and Schopenhauer is evident; some degree of influence of Buddhist and Upanishadic thought on Schopenhauer can be established" (158). This interesting essay, which was published in The Ceylon Journal of the Humanities (Vol. 1 No. 2 July, 1970), is a detailed discussion of the influence of Buddhism and the Upanishads on Schopenhauer and Freud.

The deconstruction of binary opposites is a philosophical tendency that I find in the Upanishads, in the thought of Schopenhauer, Nietzsche and, later, in the Derridian critique of metaphysics. Curiously enough, merging of opposites is not at all alien to Freudian psychoanalysis. Freud argues in "An Outline of Psychoanalysis," that in the unconscious the opposites meet; that there are no binaries. According to Freud, dreaming brings together incompatible elements. This is because in the unconscious opposites are treated as if they were identical. He writes:

"A few linguistic researchers have recognized that it was just the same in the most ancient languages and that opposites like 'strong-weak,' light-dark,' or 'high-deep' were originally expressed through the same root until two different modifications of the original word separated the two meanings from one another." (Freud 23)

According to Freud, the unconscious defies the rules of logic. It is for this reason that he describes the unconscious as the "Empire of the Illogical" (ibid). Later, for Jacques Lacan-who in many respects is Freud's successor and one of the most influential yet painfully obfuscating poststructuralists-language will become the Empire of the Illogical. Terry Eagleton commenting on Lacan writes "for Lacan the unconscious is a particular effect of language, a process of desire set in motion by difference" (Eagleton 173). If the unconscious is structured like a language, I suppose that the inverse of this argument also holds true: language is structured like the unconscious. Language, then, is beyond logic; language as Derrida claims in his essay titled "Monolingualism of the Other" is "mad about itself" (Derrida 24).

The best literary example for linguistic madness is James Joyce's monstrous "novel" Finnegans Wake. Karen Lawrence in her essay titled "Joyce and Feminism" writes "In unmasking the binary oppositions, Joyce is a precursor of deconstruction" (Lawrence, 242). Although it is difficult to argue that Joyce was influenced by 
Schopenhauer, in Joyce's notoriously difficult novel one certainly finds the influence of Hinduism. Finnegars Wake is nothing short of a theoretical pleasure cruise for a poststructuralist. Indeed, it is in many respects the quintessential poststructuralist novel. For this reason, this work is excruciatingly inaccessible and may even seem utterly incomprehensible. However, nothing is beyond comprehension nor can anything be perfectly comprehended. In line with Nietzsche's eternal recurrence and Hindu rebirth, this novel is cyclical. The last book of Finnegans Wake is saturated with references to Indian philosophy. The French Tel Quel group-a radical group of French theorists to which Derrida also belongedwas operating under the influence of Joyce and FinnegansWake. In fact Derrida in an article titled "Two Words for Joyce" announces his debt to Joyce. He writes: "Our admiration for Joyce ought to have no limit, no more than should the debt owed to the singular event of his work" (Derrida 148).

However, it is the relationship between Derrida and Nietzsche that brings Derrida into the possible genealogy of ideas that I am tracing. Gayatri Spivak in her preface to Derrida's of Grammatology discusses in great detail Nietzsche's influence on Derrida. That both Nietzsche and Freud were influenced by Schopenhauer-who was in turn influenced by the Upanishads and Buddhism-is fascinating. Derrida's critique of Freud in "Freud and the Scene of Writing" amply illustrates Freud's influence on Derridian thinking. It should also be noted that in Derrida, the subversion of binary opposites that we found in the Upanishads, Arthur Schopenhauer, Friedrich Nietzsche and Sigmund Freud, transforms into what is termed as deconstruction. Here I am not positing a direct link between Derridian thought and Eastern philosophy; rather I am drawing attention to the fact that in Derridian thought, Nietzsche's influence is crucial, and that the subversion of binary opposites is an epistemological thrust, as it were, that is found in the Upanishads and in deconstruction. However, it should be noted that Derrida is critical of German transcendental idealism. Arguably, Derrida's rejection of a "transcendental signifier" is also a rejection of the Upanishadic Brahman. It is fatuous to argue that Derridian deconstruction comes out of Upanishads and Buddhism. However, it is tenable to argue that there are certain respects in which-as I have illustrated above-deconstruction is in agreement with Eastern thought. 
Postcolonial theorists freely avail themselves of poststructuralist theory. This is because in poststructuralist theory they find a source that furnishes them with epistemological tools that enable a critique of colonialism. This should hardly surprise us since, as I have attempted to substantiate in this paper, poststructuralist thought comes significantly close to eastern epistemology. Therefore it is perhaps not fair to criticize the postcolonial sympathy for poststructuralist theory. It could be argued that poststructuralist theory is the epistemological offspring of the colonial encounter.

It is quite ironic and surprising that although many critics have commented on the influence of the Upanishads and Buddhism on Schopenhauer, and the influence of the latter on Freud and Nietzsche, scholarship seems to overlook the indirect influence of Schopenhauer on later philosophers. For that reason, the debt of poststructuralist theory to eastern thought largely remains unacknowledged. Therefore it is necessary to undertake a comprehensive, comparative philosophical study to analyse the ties between post-structuralism and eastern philosophy. Such a study would have to be ambitious and painstaking but, of course, rewarding. Mine is only a beginning.

\section{References}

Bhikku Nanajivako. Schopenhauer and Buddhism. Kandy: Buddhist Publications Society, 1988.

Derrida, Jacques. Monolingualism of the Other. California: Stanford University Press, 1998.

---. Dissemination. Continuum: London, 2004.

---.Of Grammatology, Trans. Spivak, Baltimore: John Hopkins University Press, 1976.

--- Positions, Trans. Alan Bass. London: Continuum, 2004.

---.Writing and Difference. Routledge: London, 1997.

Eagleton, Terry. An Introduction to Critical Theory. Oxford: Blackwell, 1983.

Foucault, Michel. The Archaeology of Knowledge. Trans. A.M. Sheridan Smith. London and New York: Routledge, 2003.

Freud, Sigmund. The Penguin Freud Reader. Ed. Adam Phillips. London: Penguin, 2006.

Joyce, James. Finnegans Wake. London: Faber \& Faber, 1964.

Padmasiri de Silva M.W. "Schopenhauer - A Link Between the Buddha and Freud?" The Ceylon Journal of the Humanities. Vol 1 No 2. (July, 1970): 141-58. 
Marx, Karl. 18 $8^{\text {th }}$ Brumaire of Louis Bonaparte. Moscow: Foreign Language Publishing House, 1954.

Nietzsche, Friedrich. Thus Spake Zarathustra. Trans. A. Tille. London: Heron Books, 1957.

---A Nietzsche Reader. Trans. R.J. Hollindale. London: Penguin, 1977.

---. Ecce Homo, The Birth of Tragedy. Trans. Clifton P. Fadiman. New York: The Modern Library, 1948.

Said, Edward. Orientalism. London: Penguin, 1991.

Schopenhauer, Arthur. World as Will and Idea. Trans. Jill Berman.

Ed. David Berman. London: Everyman, 2009.

Yeats. W.B. Selected Poems. London: Phoenix, 2010. 